\title{
EFFECT OF CHOLINE AND METHIONINE, TESTOSTERONE PROPIONATE, AND DIETARY PROTEIN ON NITROGEN BALANCE IN PATIENTS WITH LIVER DISEASE 1,
}

\author{
By GEORGE J. GABUZDA, JR.,3 RICHARD D. ECKHARDT,3, 4 AND \\ CHARLES S. DAVIDSON
}

\begin{abstract}
(From the Thorndike Memorial Laboratory, Second and Fourth Medical Services [Harvard], Boston City Hospital, and the Department of Medicine, Harvard Medical School, Boston)
\end{abstract}

(Submitted for publication October 27, 1949; accepted, January 9, 1950)

Choline and methionine have been administered as therapeutic agents to patients with liver disease on the basis of demonstrated beneficial effects of these agents in the dietary cirrhosis of animals $(1-6)$. The therapeutic value of such specific agents in human liver disease is difficult to assess clinically, by tests of liver functions, or by biopsy of the liver, because of the naturally occurring variations in the nature, severity, and course of the disease.

The demonstration of a favorable metabolic response following the administration of choline and methionine to patients with liver disease would provide a rationale for their therapeutic use. Indeed, such a favorable response, indicated by a sparing of urine nitrogen with resulting increased positive nitrogen balance, has been attributed to choline and methionine administered to patients with chronic liver damage maintained on adequate intakes of protein (7), and to dogs fed low protein diets $(8-10)$. In contrast, methionine administered to normal man, or to patients with infectious hepatitis failed to spare nitrogen (1113). Moreover, positive nitrogen balance can be regularly achieved in patients with chronic liver disease by providing adequate quantities of dietary protein (14). In addition, testosterone has a protein anabolic effect in normal man and in patients

\footnotetext{
1 A preliminary report of this investigation was presented at the Forty-first Annual Meeting of the American Society for Clinical Investigation, Atlantic City, May 2, 1949 (J. Clin. Invest., 1949, 28, 783).

2 The expenses of this investigation were defrayed in part by grants from Merck \& Co., Inc., Rahway, New Jersey, and from the Commission on Liver Disease, Army Epidemiological Board, Office of the Surgeon General, U. S. Army, Washington, D. C., to Harvard University.

3 U. S. Public Health Service Postdoctorate Research Fellow.

4 Present address: State University of Iowa, Department of Medicine, Iowa City, Iowa.
}

with a variety of illnesses including liver disease (15-17). The study reported here was undertaken to evaluate and compare choline and methionine, testosterone propionate, and dietary protein with regard to their effects upon the nitrogen balance in patients with liver disease. The results indicate that, of these agents, dietary protein most effectively achieves a positive nitrogen balance.

\section{MATERIAL AND METHODS}

Six patients with liver disease were selected for metabolic study. Their clinical and laboratory findings at the beginning and at the end of the studies are summarized in Table I. Five patients gave histories of chronic alcoholism. Three of these patients, A. C., M. L., and J. M., had long-standing, well-established, and stabilized cirrhosis of the liver (alcoholic). Three years prior to this study A. C. had a punch biopsy of the liver which revealed advanced hepatic cirrhosis with marked portal fibrosis. A fourth patient, R. H., had chronic cirrhosis of the liver and was acutely ill with marked jaundice and bilirubinuria, anorexia, tender hepatomegaly, and pronounced fetor hepaticus when the study was begun. The fifth patient, F. C., was deeply jaundiced, and had hepatomegaly. A liver biopsy at the time of hospital admittance revealed a marked fatty infiltration with minimal fibrosis. A sixth patient, J. H., was convalescing from a typical episode of severe infectious hepatitis, and had a negative history for alcoholism.

The patients were maintained on the Thorndike Metabolic Ward, and were ambulatory during the studies, with the exception of $R$. H., who was kept at bed rest during the initial month of hospitalization. The basal control diets provided from 0 to $100 \mathrm{Gm}$. of protein daily. The diet devoid of protein provided less than $0.2 \mathrm{Gm}$. of nitrogen daily as determined by macro-Kjeldahl analysis (18). The nitrogen intakes of the other diets were calculated from standard food tables $(19,20)$. The dietary protein consumed was derived from foods found in the usual normal diet. Fat intakes were not restricted. Each patient consumed at least $300 \mathrm{Gm}$. of carbohydrate and 2800 calories daily. The effect of each of the following supplements upon the basal nitrogen balances was de- 
termined : 1) choline chloride 5 and $d l$-methionine ${ }^{6}$ administered orally simultaneously; 2) choline chloride 5 administered orally alone; 3) testosterone propionate 7 administered intramuscularly; 4) additional increments of dietary protein. Glycine ${ }^{b}$ was also administered orally to one of the patients to test the specificity of the change in nitrogen balance observed during the administration of choline and methionine.

A control period identical to the initial control period preceded each period of supplementation in each study. The choline and methionine were given in three equally divided doses with meals. The nitrogen content of the choline preparation was determined by macro-Kjeldahl analysis. $d l$-Methionine and glycine were administered as the crystalline materials mixed in $30 \mathrm{Gm}$. of jelly. The nitrogen content of these amino acids was calculated from the analytical data supplied by the manufacturer.

5 "Choline Chloride Solution," supplied by the Abbott Laboratories, North Chicago, Illinois.

- Supplied by Merck \& Co., Inc., Rahway, New Jersey.

7 "Neo-Hombreol," supplied by Roche-Organon, Inc., Nutley, New Jersey.
Daily urine and pooled stool nitrogen analyses were made by the standard micro and macro-Kjeldahl techniques. Pooled stools were obtained during each control and experimental period. Since there were no significant variations in the stool nitrogen content during these periods, stool nitrogen output was considered to be constant throughout each study, and the averaged values were used in the calculation of the nitrogen balance data.

Tests of liver functions done at intervals during the studies included serum bilirubin concentration (21), thymol turbidity (22) and flocculation, retention of intravenously administered bromsulphalein dye $(5 \mathrm{mgm}$. per kilogram body weight at $\mathbf{4 5}$ minutes), total serum protein and albumin concentrations (23), urinary urobilinogen (24), and urinary bilirubin (25).

\section{RESULTS}

\section{Nitrogen Balance}

The first patient studied (J. M., Figure 1, Table II) received a basal diet providing only $50 \mathrm{Gm}$. of

TABLE I

Clinical and laboratory data of patients with liver disease

\begin{tabular}{|c|c|c|c|c|c|c|c|c|c|c|c|c|}
\hline \multirow{2}{*}{ 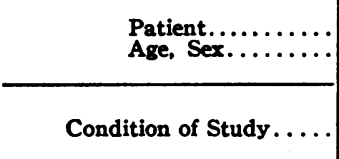 } & \multicolumn{2}{|c|}{ A. c. $_{\sigma^{3}}$} & \multicolumn{2}{|c|}{ M. L. } & \multicolumn{2}{|c|}{$J_{56} \cdot \underset{\sigma^{j}}{M}$} & \multicolumn{2}{|c|}{$\underset{35}{\mathrm{~J}} \mathrm{O}_{\mathrm{O}^{\prime}}$} & \multicolumn{2}{|c|}{$\frac{\text { R. }}{38}$ H. $^{+}$} & \multicolumn{2}{|c|}{$\underset{36}{\text { F. }} \mathrm{C}$. } \\
\hline & $\begin{array}{l}\text { Begin- } \\
\text { ning }\end{array}$ & End & $\underset{\text { ning }}{\substack{\text { Begin- } \\
\text { nat }}}$ & End & $\begin{array}{l}\text { Begin- } \\
\text { ning }\end{array}$ & End & $\begin{array}{l}\text { Begin- } \\
\text { ning }\end{array}$ & End & $\begin{array}{c}\text { Begin- } \\
\text { ning }\end{array}$ & End & $\underset{\substack{\text { Begin- } \\
\text { ning }}}{\text { But }}$ & End \\
\hline Ascites* & 0 & 0 & $1+$ & 0 & $1+$ & $\mathbf{0}$ & 0 & 0 & $1+$ & 0 & 0 & 0 \\
\hline Edema* & $2+$ & 0 & $2+$ & 0 & 0 & \pm & $\mathbf{0}$ & 0 & $1+$ & $\mathbf{0}$ & $\mathbf{0}$ & 0 \\
\hline Vascular spiders* & $4+$ & $4+$ & $4+$ & $4+$ & $2+$ & $2+$ & 0 & 0 & $1+$ & $1+$ & 0 & 0 \\
\hline Liver size† & 7 & 7 & 11 & 10 & 20 & 17 & 2 & 0 & 12 & 9 & 12 & 6 \\
\hline Spleen sizet & 13 & 12 & 0 & 0 & 0 & 0 & 0 & 0 & 2 & 0 & 0 & 0 \\
\hline $\begin{array}{l}\text { Serum bilirubin, } \\
\text { mgm. per } 100 \text { cc. }\end{array}$ & 2.0 & 1.5 & 2.7 & 2.5 & 1.1 & 1.4 & 2.3 & 0.4 & 18.6 & 5.3 & 8.9 & 0.6 \\
\hline Thymol turbidity $\ddagger$ & 3.9 & 3.7 & 3.8 & 5.3 & 4.0 & 4.1 & 3.3 & 2.2 & 5.4 & 4.2 & 7.0 & 1.6 \\
\hline Thymol flocculation* & $4+$ & $4+$ & $4+$ & $4+$ & $3+$ & $3+$ & 0 & 0. & 0 & 0 & 0 & 0 \\
\hline Urine Bile* & 0 & 0 & $3+$ & 0 & 0 & 0 & 0 & 0 & $4+$ & TR & $4+$ & 0 \\
\hline Urine urobilinogen & $1: 20$ & - & $1: 64$ & - & $1: 64$ & - & $1: 4$ & $1: 16$ & $1: 32$ & $1: 64$ & $1: 128$ & $1: 2$ \\
\hline \multirow{2}{*}{$\begin{array}{l}\text { Serum } \\
\text { protein } \\
\text { Gm. per } \\
100 \text { cc. }\end{array}$} & 7.1 & 6.9 & 5.7 & 5.5 & 7.2 & 8.0 & 6.9 & 6.7 & 6.1 & 6.2 & 6.8 & \\
\hline & 2.5 & 3.0 & 2.4 & 2.4 & 3.4 & 3.5 & 4.5 & 4.4 & 2.1 & 2.1 & 4.0 & 4.8 \\
\hline $\begin{array}{l}\text { Bromsulphalein \% reten- } \\
\text { tion }\end{array}$ & 32 & 30 & 34 & 32 & 38 & 37 & - & 2 & - & 42 & 52 & 1 \\
\hline $\begin{array}{l}\text { Prothrombin \% normal } \\
\text { concentration }\end{array}$ & 36 & - & 41 & - & 49 & - & - & - & 30 & 38 & 100 & 97 \\
\hline
\end{tabular}

- 0 to 4 +.

+ Cm. below costal margin.

$\ddagger$ Normal value less than 1.7 cc. BaSO. 
TABLE II

Effect of choline and methionine, testosterone propionate, and dietary protein on nitrogen balance in patients with liver disease

\begin{tabular}{|c|c|c|c|c|c|c|c|c|c|}
\hline \multirow{2}{*}{\multicolumn{2}{|c|}{$\frac{\text { Patient................. prolein per day...... }}{\text { Basal Diet Gm. }}$}} & \multirow{3}{*}{$\frac{\text { A. C. }}{100}$} & \multirow{3}{*}{ M. L. } & \multirow{3}{*}{$\frac{\text { J. M. }}{50}$} & \multirow{3}{*}{ J. H. } & \multicolumn{2}{|c|}{ R. H. } & \multicolumn{2}{|c|}{ F. C. } \\
\hline & & & & & & 25 & 50 & 0 & 100 \\
\hline Period of Study & $\begin{array}{l}\text { Nitrogen* } \\
G m \text {. per day }\end{array}$ & & & & & & & & \\
\hline Control & $\begin{array}{l}\text { Intake } \\
\text { Output } \\
\text { Balance }\end{array}$ & $\begin{array}{r}16.0 \\
10.6 \\
+\quad 5.4\end{array}$ & $\begin{array}{r}16.0 \\
9.0 \\
+\quad 7.0\end{array}$ & $\begin{array}{r}8.0 \\
6.4 \\
+\quad 1.6\end{array}$ & $\begin{array}{r}12.0 \\
8.7 \\
+\quad 3.3\end{array}$ & $\begin{array}{r}3.9 \\
8.1 \\
-4.2\end{array}$ & $\begin{array}{r}8.2 \dagger \\
7.3 \\
+0.9\end{array}$ & $\begin{array}{r}0.1 \\
2.6 \\
-\quad 2.5\end{array}$ & $\begin{array}{r}16.3 \dagger \\
9.0 \\
+\quad 7.3\end{array}$ \\
\hline $\begin{array}{l}\text { Control +choline and } \\
\text { methionine }\end{array}$ & $\begin{array}{l}\text { Intake } \\
\text { Output } \\
\text { Balance }\end{array}$ & $\begin{array}{r}16.8 \\
11.4 \\
+\quad 5.4\end{array}$ & $\begin{array}{r}16.8 \\
9.9 \\
+\quad 6.9\end{array}$ & $\begin{array}{r}8.8 \\
6.9 \\
+\quad 1.9\end{array}$ & $\begin{array}{r}13.6 \\
9.9 \\
+\quad 3.7\end{array}$ & $\begin{array}{r}5.2 \\
8.2 \\
-3.0\end{array}$ & $\begin{array}{r}9.5 \\
7.5 \\
+\quad 2.0\end{array}$ & $\begin{array}{r}1.3 \\
2.3 \\
-\quad 1.0\end{array}$ & $\begin{array}{r}17.5 \\
10.2 \\
+\quad 7.3\end{array}$ \\
\hline Control & $\begin{array}{l}\text { Intake } \\
\text { Output } \\
\text { Balance }\end{array}$ & $\begin{array}{r}16.0 \\
10.2 \\
+\quad 5.8\end{array}$ & $\begin{array}{r}16.0 \\
9.2 \\
+6.8\end{array}$ & $\begin{array}{r}8.0 \\
6.6 \\
+\quad 1.4\end{array}$ & $\begin{array}{r}12.0 \\
9.4 \\
+\quad 2.6\end{array}$ & $\begin{array}{r}4.0 \\
8.0 \\
-4.0\end{array}$ & $\begin{array}{r}8.2 \\
6.4 \\
+\quad 1.8\end{array}$ & $\begin{array}{r}0.2 \\
3.5 \\
-\quad 3.3\end{array}$ & $\begin{array}{r}16.3 \\
9.3 \\
+\quad 7.0\end{array}$ \\
\hline $\begin{array}{l}\text { Control + test. prop. or } \\
\text { glycine as indicated }\end{array}$ & $\begin{array}{l}\text { Intake } \\
\text { Output } \\
\text { Balance }\end{array}$ & $\begin{array}{r}16.0 \ddagger \\
7.6 \\
+8.4\end{array}$ & $\begin{array}{r}16.0 \ddagger \\
7.9 \\
+8.1\end{array}$ & $\begin{array}{r}8.0 \ddagger \\
5.4 \\
+2.6\end{array}$ & & & $\begin{array}{r}9.68 \\
6.2 \\
+\quad 3.4\end{array}$ & & \\
\hline Control & $\begin{array}{l}\text { Intake } \\
\text { Output } \\
\text { Balance }\end{array}$ & $\begin{array}{r}16.0 \\
10.2 \\
+\quad 5.8\end{array}$ & $\begin{array}{r}16.0 \\
8.8 \\
+\quad 7.2\end{array}$ & $\begin{array}{r}8.0 \\
6.6 \\
+\quad 1.4\end{array}$ & & & $\begin{array}{r}8.2 \\
5.9 \\
+\quad 2.3\end{array}$ & & \\
\hline $\begin{array}{l}\text { Control+dietary pro- } \\
\text { tein }\end{array}$ & $\begin{array}{l}\text { Intake } \\
\text { Output } \\
\text { Balance }\end{array}$ & $\begin{array}{r}24.0 \\
11.6 \\
+12.4\end{array}$ & & $\begin{array}{r}14.0 \\
10.0 \\
+\quad 4.0\end{array}$ & $\begin{array}{r}20.0 \\
13.6 \\
+\quad 6.4\end{array}$ & $\begin{array}{r}8.2 \\
7.6 \\
+0.6\end{array}$ & $\begin{array}{r}12.2 \\
6.7 \\
+\quad 5.5\end{array}$ & $\begin{array}{r}16.0 \\
7.7 \\
+\quad 8.3\end{array}$ & \\
\hline
\end{tabular}

* Changes in nitrogen output reflect changes in urine nitrogen, since stool nitrogen output was constant throughout each study.

$\dagger$ Average values for the nine days during this second period of study preceding choline and methionine (R. H.), and choline (F. C.) administration.

$\ddagger$ Testosterone propionate.

$\$$ Glycine.

protein daily. Nitrogen balance averaged +1.6 $\mathrm{Gm}$. daily during the nine-day initial control period. During the administration of choline chloride and $d l$-methionine $(4.5 \mathrm{Gm}$. of each simultaneously orally daily for six days) a part of the nitrogen contained in these agents was retained. Urine nitrogen thus increased toward the end of the six-day period. The administration of testosterone propionate intramuscularly produced a decrease in urine nitrogen excretion and an increase in average daily nitrogen balance to +2.6 $\mathrm{Gm}$. for the six-day period during, and for the six-day period following the therapy. Twelve days following the last injection of testosterone propionate, the basal $50 \mathrm{Gm}$. protein diet was increased to $75 \mathrm{Gm}$. daily for a nine-day period, and then to $100 \mathrm{Gm}$. daily for an additional nine days. The average nitrogen balances were +3.5 and $+4.4 \mathrm{Gm}$., respectively, during these periods of dietary protein supplementation. (These last two periods are averaged in Table II.)
Similar results were obtained in two other patients (A. C., Figure 2, Table II, and M. L., Figure 3, Table II) observed during the supplementation of the $100 \mathrm{Gm}$. protein diet with choline and methionine, and then with testosterone propionate, in the same quantities of each as employed in J. M. In both these patients the average daily excretion of nitrogen in the urine increased by a quantity of nitrogen equivalent to that contained in the daily dose of choline and methionine during the administration of these agents.

Nine Gm. each of choline chloride and $d l$ methionine were administered to J. H. (Figure 4, Table II) orally daily for nine days while this patient received a $75 \mathrm{Gm}$. protein diet. The average daily urine nitrogen excretion before and during such therapy was 7.5 and $8.7 \mathrm{Gm}$., and the average daily nitrogen balance was +3.3 and $+3.7 \mathrm{Gm}$., respectively. During the first six days of choline and methionine administration the nitrogen balance was more positive by a quantity 


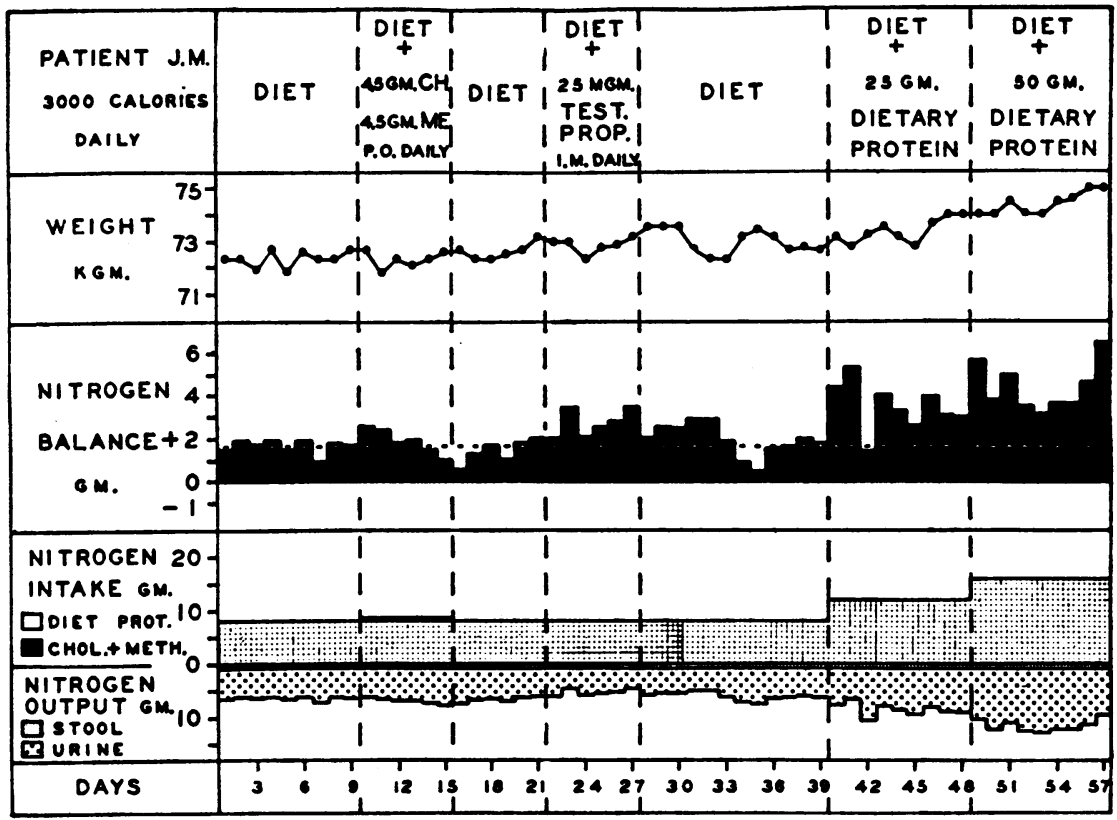

FIG. 1

The dotted horizontal line in this figure and in Figures $2-4$ indicates the averaged daily nitrogen balance obtained during the initial control period.

of nitrogen equivalent to that contained in the administered agents. Subsequently, however, urine nitrogen excretion increased and nitrogen balance became less positive than during the initial control period. After metabolic equilibrium was reestablished with positive nitrogen balance averaging 2.6 $\mathrm{Gm}$. per day, the addition of $50 \mathrm{Gm}$. of dietary protein to the basal regime for a 12-day period

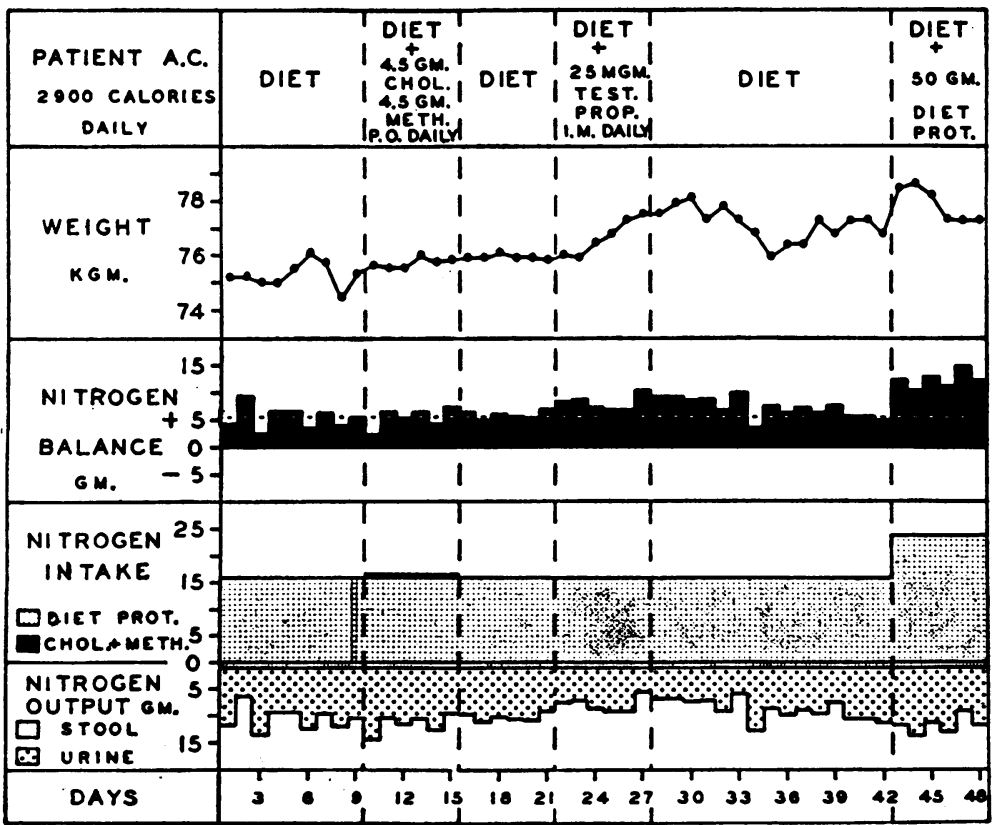

FIG. 2

(See legend, Figure 1) 




FIG. 3

(See legend, Figure 1)

was accompanied by an increase in average daily positive nitrogen balance to $6.4 \mathrm{Gm}$.

Patient R. H. (Figure 5, Table II) initially received a $25 \mathrm{Gm}$. protein diet. On this control regime average daily nitrogen excretion was 8.1
Gm. (6.9 Gm. urine nitrogen, 1.2 Gm. stool nitrogen), and negative nitrogen balance averaging $-4.2 \mathrm{Gm}$. daily prevailed. Nine Gm. of choline chloride and $6 \mathrm{Gm}$. of $d l$-methionine were given orally daily for six days. During this period the

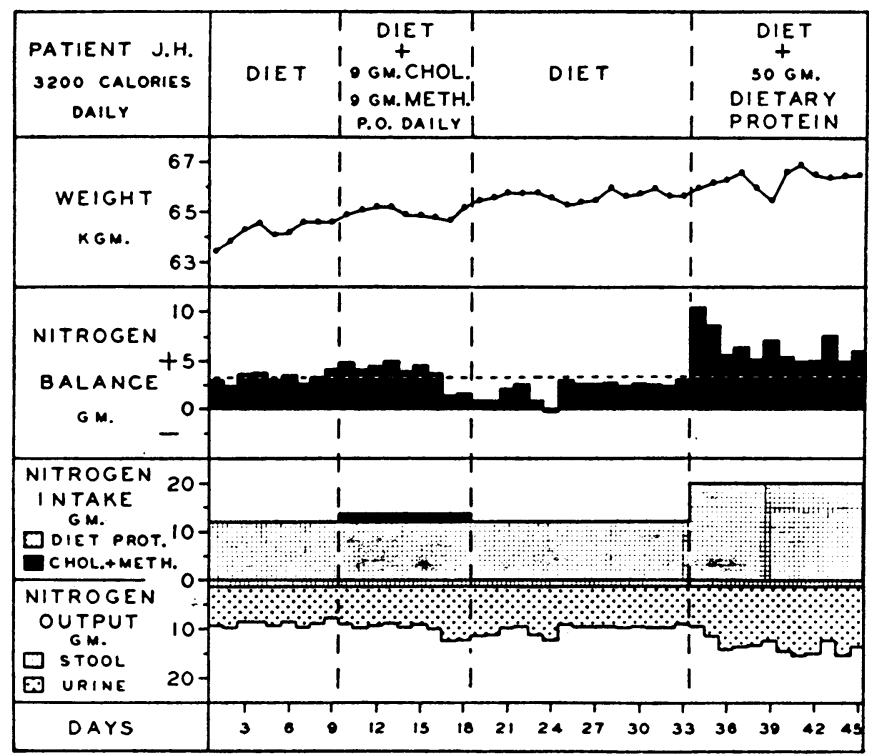

FIG. 4

(See legend, Figure 1) 


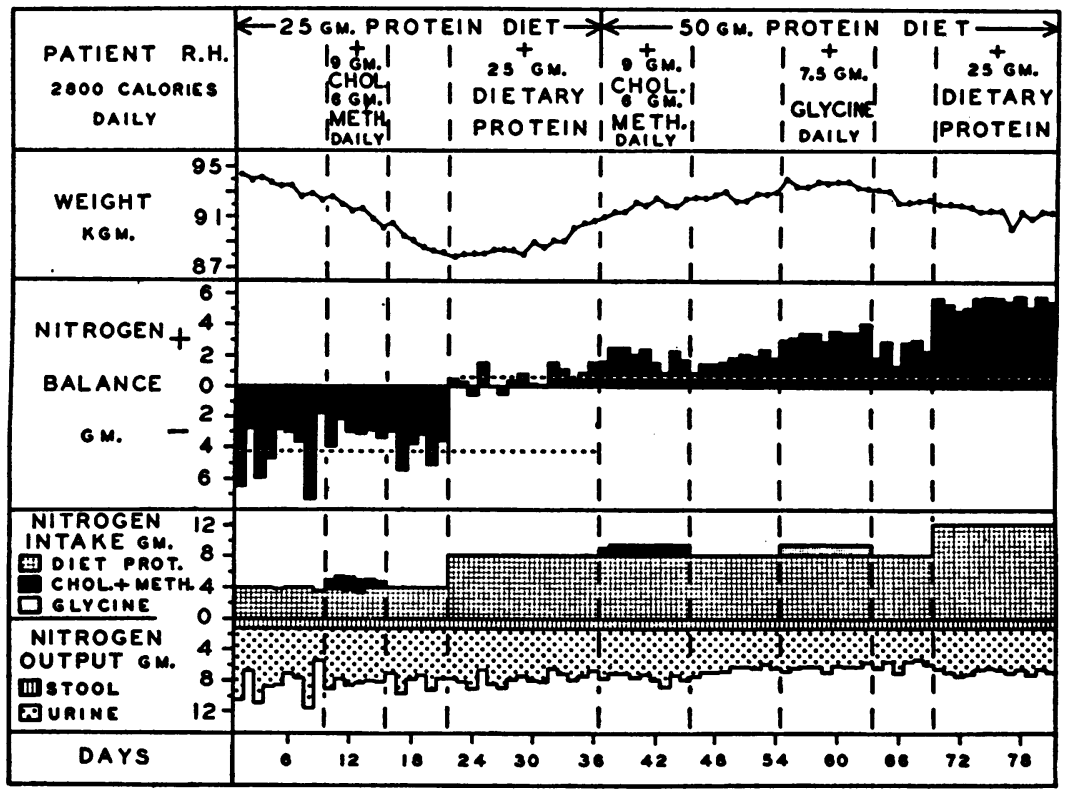

FIG. 5

The averaged daily nitrogen balance obtained during days 1 to 9 inclusive, and days 22 to 36 inclusive, is indicated by the lower and upper dotted horizontal lines, respectively.

average daily excretion of nitrogen in the urine was $7.0 \mathrm{Gm}$., and the nitrogen balance was therefore less negative by an amount of nitrogen equivalent to that contained in the administered agents. This patient promptly established and maintained nitrogen equilibrium when the dietary protein intake was increased by only $25 \mathrm{Gm}$. of additional dietary protein daily. The $50 \mathrm{Gm}$. protein diet was then supplemented with the same daily oral dose of choline and methionine for nine days. Again urine nitrogen excretion was unaltered, and an average daily increase in nitrogen balance of $1.0 \mathrm{Gm}$. was observed. This increase was no more than could be accounted for by retention of part of the nitrogen contained in the administered choline and methionine. A marked positive nitrogen balance of $5.5 \mathrm{Gm}$. daily for 12 days accompanied the addition of $25 \mathrm{Gm}$. of dietary protein to the $50 \mathrm{Gm}$. protein diet.

To determine whether or not the nitrogen balance changes accompanying the administration of choline and methionine were specific, $7.5 \mathrm{Gm}$. of glycine were given orally to $\mathrm{R}$. $\mathrm{H}$. for nine days while he continued to receive the $50 \mathrm{Gm}$. protein diet (Figure 5, Table II). This amount of glycine was calculated to contain a quantity of nitrogen equivalent to the nitrogen contained in the previously administered choline and methionine. An increase in daily positive nitrogen balance occurred concomitant with glycine administration. This increase approximated the amount of nitrogen contained in the ingested glycine, and was of similar magnitude to that noted when an equivalent amount of nitrogen was given as choline and methionine.

The daily urine nitrogen excretion gradually decreased throughout the study of patient $\mathrm{R}$. $\mathrm{H}$. This progressive change was not influenced by the administration of choline and methionine, of dietary protein, or of glycine.

Twelve $\mathrm{Gm}$. of choline chloride without methionine were given daily to patient F. C. (Figure 6, Table II) for six days in each of two contiguous studies. A diet devoid of protein was provided during the first study, while the diet contained $100 \mathrm{Gm}$. of protein during the second. Control urine nitrogen excretion initially was at an "endogenous" level, and did not increase during choline administration, indicating the quantitative retention of the nitrogen contained in the administered choline. The nitrogen balance remained negative throughout this period. Marked 
positive nitrogen balance occurred when dietary protein was provided. The addition of choline to the $100 \mathrm{Gm}$. protein diet did not alter the nitrogen balance from the control which had been observed during the nine-day period preceding choline therapy, urine nitrogen excretion increasing by a quantity of nitrogen equivalent to that contained in the choline given.

\section{Clinical}

All patients presented some evidence of clinical improvement during the initial control periods. In none of these patients could alterations in their hospital courses, as determined clinically or by laboratory tests of liver functions, be specifically attributed to the administration of choline and methionine, of testosterone propionate, or of supplements of dietary protein.

The tests of liver functions determined at intervals throughout the study revealed no significant changes in the patients with well-established hepatic cirrhosis (A. C., M. L., and J. M.). These patients gradually improved clinically, but there was no appreciable change in liver or in spleen size during these studies. Moderate ankle edema which was present initially in A. C. gradually subsided. M. L. (Figure 3) lost weight during the first week of study. This was accompanied by a diuresis and loss of ascites and edema. J. M. underwent a similar diuresis just prior to the study. Subsequent gains in body weight shown by these patients were unaccompanied by clinical evidence of fluid retention. J. H., who was recovering from severe infectious hepatitis, continued to improve. This patient's liver became non-palpable, and serum bilirubin concentration and bromsulphalein excretion tests were normal by the time the study was completed.

R. H. slowly improved clinically during hospitalization. The liver became non-tender during the first week, and decreased moderately in size during the study. A loss of body weight and mobilization of ascites and edema occurred during the first three-week period when the $25 \mathrm{Gm}$. protein diet was given and negative nitrogen balance prevailed. In fact, ascites and edema were not detectable by the time choline and methionine were first administered. Subjective improvement with return of appetite, as evidenced by the ease with which food was consumed, gradually occurred.

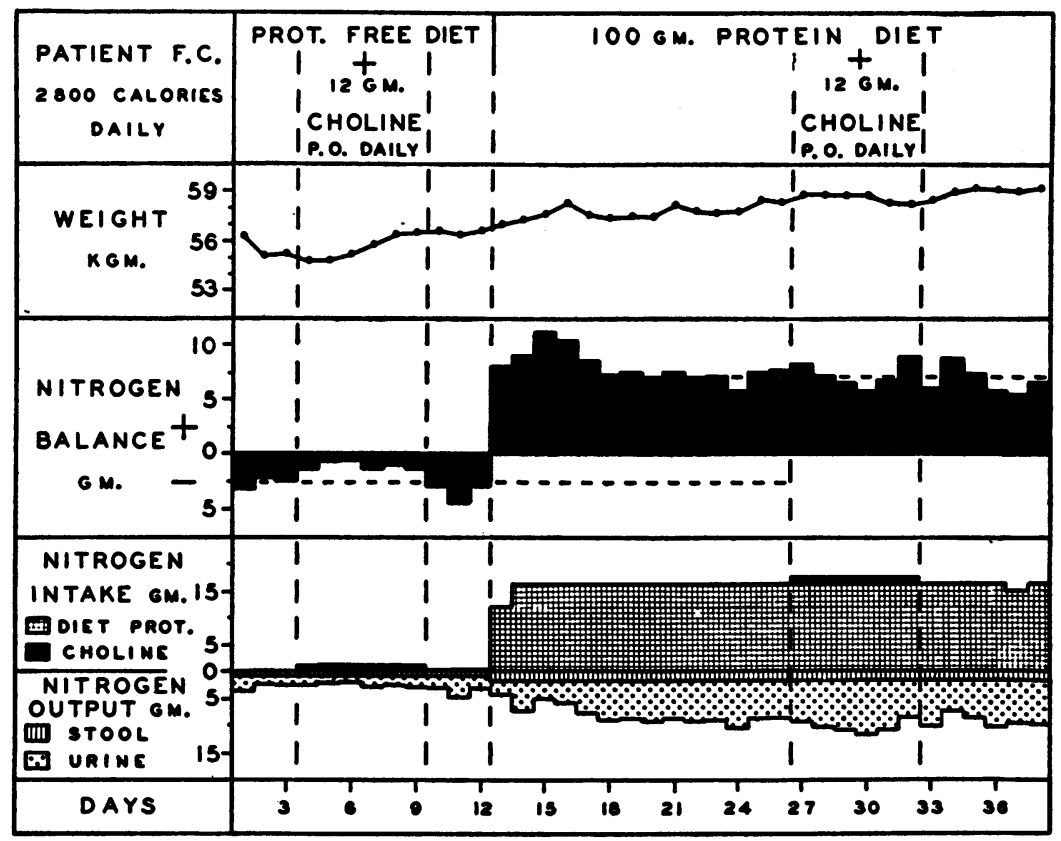

Frg. 6

The averaged daily nitrogen balance obtained during days 1 to 3 inclusive, and days 18 to 26 inclusive, is indicated by the lower and upper dotted horizontal lines, respectively. 
Hepatic fetor, at first marked, became less pronounced, and gradually became not detectable. Bilateral gynecomastia appeared after two months of study, and then slowly subsided. The total serum bilirubin concentration decreased from 18.6 to $5.3 \mathrm{mgm}$. per cent and bilirubinuria was barely detectable by the end of the study, although bromsulphalein excretion was markedly abnormal.

F. C. improved clinically before choline was administered and while a diet devoid of protein but adequate in calories was provided. The improvement was demonstrated by a decrease in serum bilirubin concentration from 8.9 to $3.0 \mathrm{mgm}$. per cent, in bilirubinuria from $4+$ to $1+$, in urinary urobilinogen from $1: 128$ to $1: 64$, and in the retention of bromsulphalein dye from 52 to 18 per cent. This initial marked improvement continued, and at the end of the study laboratory tests revealed the following: serum bilirubin $0.6 \mathrm{mgm}$. per cent, absent bilirubinuria, urine urobilinogen 1: 2 , and bromsulphalein retention 1 per cent. The liver receded from 12 to $6 \mathrm{~cm}$. below the costal margin, the patient felt well, and general physical examination was otherwise within normal limits.

\section{DISCUSSION}

A relationship of dietary deficiency of choline, of methionine, and of protein to the production of hepatic cirrhosis in experimental animals is well established $(1-6)$. The role of these agents in the causation and treatment of liver disease in man remains obscure. Indeed, the difficulties encountered in evaluating such agents in human liver disease are demonstrated in this study, since all patients showed definite evidence of improvement during the relatively brief initial control periods, regardless of the type or duration of their disease, and regardless of the diets provided. In most instances this initial improvement was at least as marked as that observed during the subsequent study periods. For example, patient F. C., whose liver biopsy and initial studies indicated a severe degree of fatty alcoholic cirrhosis of the liver, showed marked improvement while receiving a diet devoid of protein before choline was administered. It was not possible to attribute further favorable clinical and laboratory changes to the choline or to the dietary protein subsequently administered, because of the marked initial im- provement which occurred shortly after hospitalization. Similar clinical and laboratory improvement immediately upon hospitalization has been observed in this laboratory in other patients with acute fatty alcoholic cirrhosis of the liver who were given diets deficient in protein but calorically adequate (26).

Because of the difficulties encountered in attempting to evaluate clinically the efficacy of specific therapeutic agents in liver disease, the demonstration of a favorable metabolic alteration attributable to choline and methionine administered to such patients would provide a rationale for therapy with these agents. That such a metabolic alteration might occur with regard to protein utilization seemed possible, since these agents might be preferentially utilized for lipotropic or detoxification purposes by patients with liver disease, thereby decreasing their availability for the maintenance of nitrogen balance. In fact, a relative deficiency of these agents might exist, since there is an initial increase in the rate of phospholipid turnover following their administration to patients with liver disease (27). Dietary methionine might in this case be the limiting essential amino acid for the maintenance of nitrogen balance and thus would be expected to produce an increase in the retention of nitrogen when administered as a supplement to a diet. Such protein anabolic properties have been recently attributed to choline and methionine administered orally to patients with liver disease receiving adequate intakes of protein (7). The present study fails to confirm this observation of a sparing of urine nitrogen attributable to choline and methionine administered orally to patients with liver disease when they are provided with diets adequate to achieve positive nitrogen balance. These patients on $100 \mathrm{Gm}$. protein diets excreted in the urine during the administration of choline and methionine quantities of nitrogen equivalent to the nitrogen contained in these agents, and nitrogen balance was not altered by such therapy as compared to control periods.

Because of anorexia, patients with cirrhosis of the liver are not always able to ingest quantities of protein adequate for nitrogen balance. Therefore, it seemed possible that a nitrogen sparing effect attributable to the lipotropic agents might occur in patients receiving deficient diets even though a sparing of nitrogen by methionine does 
not occur in normal man or in patients with infectious hepatitis $(11,12,13)$. Nitrogen retention as measured by nitrogen balance was slightly increased during the administration of choline and methionine to the patients in this study receiving 0 to $50 \mathrm{Gm}$. protein diets, and in negative or only slightly positive nitrogen balance. In no instance, however, did this increase exceed the quantity of nitrogen contained in the agents given. Moreover, in all patients, urine nitrogen excretion was unaltered or increased during the administration of choline and methionine, as compared to the control periods. Thus urine nitrogen was not spared in any of the patients studied who were provided with diets of varied protein content resulting in nitrogen balances ranging from -4.2 to $+6.8 \mathrm{Gm}$. daily. The retention of the nitrogen contained in glycine administered orally to patient R. H. (Figure 5) further demonstrates that the slight increases in nitrogen retention observed during the administration of choline and methionine to these patients were not due to the correction of specific limiting deficiencies of methionine, or of choline.

Choline was administered without methionine to one patient (F. C., Figure 6) while she was receiving a diet devoid of protein, and again when a $100 \mathrm{Gm}$. protein diet was provided. In these instances, choline behaved with regard to its effect upon the nitrogen balance and urine nitrogen in a manner identical to that observed in the other patients given choline and methionine simultaneously.

The failure of some patients with liver disease to display a nitrogen sparing effect during periods of choline and methionine administration has been attributed, in part, to their inability to respond to a "protein anabolic stimulus" (7). However, the patients in the present study were able to respond to such a stimulus as indicated by the decreases in urine nitrogen and the concomitant increases in positive nitrogen balance during and immediately following the administration of testosterone propionate. It should be noted that these positive responses were obtained at the same levels of dietary protein intake and urine nitrogen excretion at which choline and methionine had previously failed to spare urine nitrogen (Table II). Furthermore, the magnitude of the nitrogen balance responses obtained with testosterone in the present study is similar to that reported for the anabolic effect of comparable doses of this hormone administered to normal adult man (15). The most marked increases in nitrogen retention regularly followed the addition of dietary protein to the basal control regimes, in contrast to the changes observed during the administration of choline and methionine, or of testosterone propionate. This response to dietary protein indicated that the patients were able to utilize dietary protein when provided, and that they were depleted of protein. In this study positive nitrogen balance was most effectively and economically achieved by the simple expedient of providing adequate quantities of dietary protein, rather than by supplementation of the diet with choline and methionine, or by the intramuscular administration of testosterone propionate.

\section{SUMMARY AND CONCLUSIONS}

Five patients with cirrhosis of the liver and one patient with infectious hepatitis were maintained on basal diets providing from 0 to $100 \mathrm{Gm}$. of protein daily. Initial control nitrogen balances averaged from -4.2 to $+7.0 \mathrm{Gm}$. daily. The effect of supplements of choline and $d l$-methionine, of testosterone, and of dietary protein upon these balances was determined. In each study a period of supplementation was preceded and followed by identical control periods.

The oral administration of choline chloride and $d l$-methionine simultaneously to these patients did not spare urine nitrogen. In no instance did increases in nitrogen balance during the administration of these agents exceed the quantity of nitrogen they contained. This retention of nitrogen occurring in some patients was non-specific, since the nitrogen contained in glycine administered orally was similarly retained. Choline administered without methionine behaved in a manner identical to that observed during periods of simultaneous choline and methionine administration.

Testosterone propionate was administered intramuscularly to three of the patients. Their ability to respond to this protein anabolic stimulus was demonstrated by decreases in urine nitrogen and increases in nitrogen balance occurring at the same levels of dietary protein intake and urine nitrogen excretion at which choline and methionine had previously failed to spare urine nitrogen. 
Increases in dietary protein of 25 to $50 \mathrm{Gm}$. daily were accompanied by the most marked increases in nitrogen retention in these patients.

No alterations in the course of these patients, as determined clinically or by laboratory tests of liver function, could be attributed specifically to the administration of choline and methionine, of testosterone propionate, or of supplements of dietary protein.

Although testosterone propionate had a protein anabolic effect in these patients with liver disease, it is concluded that positive nitrogen balance was most effectively achieved by adequate dietary protein. A sparing of urine nitrogen could not be attributed to choline and methionine administered orally.

\section{ACKNOWLEDGMENTS}

The authors wish to thank the Misses Alice Ballou, Beatrice Bernstein, Ellen Doyle, and Carol Roland for technical assistance; the Misses Kathleen Clinton and Jeanne Murray for preparing and calculating the diets used; and Mrs. Dorothy Conlon, Mrs. Margaret Ransom, and the Misses Helen Doherty and Katherine Fay of the Nursing Staff on the Thorndike Metabolic Ward.

\section{BIBLIOGRAPHY}

1. Best, C. H., and Huntsman, M. E., The effects of the components of lecithine upon deposition of fat in the liver. J. Physiol., 1932, 75, 405.

2. György, P., Experimental hepatic injury. Am. J. Clin. Path., 1944, 14, 67.

3. Daft, F. S., Sebrell, W. H., and Lillie, R. D., Production and apparent prevention of a dietary liver cirrhosis in rats. Proc. Soc. Exper. Biol. \& Med., 1941, 48, 228.

4. Sellers, E. A., Lucas, C. C., and Best, C. H., The lipotropic factors in experimental cirrhosis. Brit. M. J., 1948, 1, 1061.

5. Himsworth, H. P., and Glynn, L. E., Massive hepatic necrosis and diffuse hepatic fibrosis (acute yellow atrophy and portal cirrhosis): their production by means of diet. Clin. Sc., 1944, 5, 93.

6. Rich, A. R., and Hamilton, J. D., Experimental production of cirrhosis by means of deficient diet. Bull. Johns Hopkins Hosp., 1940, 66, 185.

7. Kinsell, L. W., Michaels, G. D., Barton, H. C., and Weiss, H. A., Protein balance studies in patients with liver damage. II. The role of lipotropic agents. Ann. Int. Med., 1948, 29, 881.

8. Miller, L. L., The metabolism of $d l$-methionine and $l$ cystine in dogs on a very low protein diet. J. Biol. Chem., 1944, 152, 603.
9. Allison, J. B., Anderson, J. A., and Seeley, R. D., Some effects of methionine on the utilization of nitrogen in the adult dog. J. Nutrition, 1947, 33, 361.

10. Brush, M., Willman, W., and Swanson, P. P., Amino acids in nitrogen metabolism with particular reference to the role of methionine. J. Nutrition, 1947, 33, 389.

11. Johnson, R. M., Deuel, H. L., Jr., Morehouse, M. G., and Mehl, J. W., The effect of methionine upon the urinary nitrogen in men at normal and low levels of protein intake. J. Nutrition, 1947, 33, 371.

12. Cox, W. M., Jr., Mueller, A. J., Elman, R., Albanese, A. A., Kemmerer, K. S., Barton, R. W., and Holt, L. E., Jr., Nitrogen retention studies on rats, dogs and man; the effect of adding methionine to an enzymic casein hydrolysate. J. Nutrition, 1947, 33, 437.

13. Popper, H., Kozoll, D. D., Steigmann, F., and Mok, W. T., Has methionine a protein sparing effect in acute infectious hepatitis? Am. J. M. Sc., 1948, 215, 624.

14. Post, J., and Patek, A. J., Jr., Serum proteins in cirrhosis of the liver. II. Nitrogen balance studies on five patients. Arch. Int. Med., 1942, 69, 83.

15. Kenyon, A. T., Knowlton, K., Sandiford, I., Koch, F. C., and Lotwin, G., A comparative study of the metabolic effects of testosterone propionate in nor$\mathrm{mal} \mathrm{men}$ and women and in eunuchoidism. Endocrinology, 1940, 26, 26.

16. Reifenstein, E. C., Jr., The protein-anabolic-activity of steroid compounds in man. A tabulation of substances tested to December 1942. Supplement to minutes of First Conference on Bone and Wound Healing, New York, September, 1942. (Sponsored by Josiah Macy, Jr. Foundation.)

17. Kinsell, L. W., Factors affecting the protein balance in the presence of chronic viral liver damage. Gastroenterology, 1948, 11, 672.

18. Eckhardt, R. D., Lewis, J. H., Murphy, T. L., Batchelor, W. H., and Davidson, C. S., Chemical, clinical, and immunological studies on the products of human plasma fractionation. XXXIV. Comparative studies on the nutritive value of orally and intravenously administered human serum albumin in man. J. Clin. Invest., 1948, 27, 119.

19. Bridges, M. A., and Mattice, M. R., Food and Beverage Analyses. Lea \& Febiger, Philadelphia, 1942, Ed. 2.

20. Bowes, A. de P., and Church, C. F., Food Values of Portions Commonly Used. Available from Anna de Planter Bowes, 311 S. Juniper St., Philadelphia 7, 1944, Ed. 5.

21. Ducci, H., and Watson, C. J., The quantitative determination of the serum bilirubin with special reference to the prompt-reacting and the chloroform-soluble types. J. Lab. \& Clin. Med., 1945, 30, 293.

22. Ley, A. B., Lewis, J. H., and Davidson, C. S., The 
quantitative determination of the thymol turbibity reaction of serum. J. Lab. \& Clin. Med., 1946, 31, 910.

23. Howe, P. E., The use of sodium sulfate as the globulin precipitant in the determination of proteins in blood. J. Biol. Chem., 1921, 49, 93.

24. Wallace, G. B., and Diamond, J. S., The significance of urobilogen in the urine as a test for liver function, with a description of a simple quantitative method for its estimation. Arch. Int. Med., 1925, 35, 698.

25. Watson, C. J., and Hawkinson, V., Semiquantitative estimation of bilirubin in the urine by means of the barium-strip modification of Harrison's test. J. Lab. \& Clin. Med., 1946, 31, 914.

26. Eckhardt, R. D., Zamcheck, N., Sidman, R. L., Gabuzda, G. J., Jr., and Davidson, C. S., Effect of protein starvation and of protein feeding on the clinical course, liver function, and liver histochemistry of three patients with active fatty alcoholic cirrhosis. J. Clin. Invest., 1950, 29, 227.

27. Cayer, D., and Cornatzer, W. E., The effects of choline and methionine on phospholipide formation in patients with liver disease as measured by radioactive phosphorus. Science, 1949, 109, 613. 